\title{
JAN SANDNER
}

Institute of Ecology and Bioethics, Cardinal Stefan Wyszyński University, Warsaw

\section{Selected problems of holistic management of the natural environment with the concept of sustainable development, as the basis for the establishment of a scientific environmental protection discipline}

Słowa kluczowe: ochrona środowiska, zarządzanie naturalnym środowiskiem, rozwój zrównoważony, holistyczna edukacja ekologiczna, ekosystemy.

Key words: management of the natural environmental, development, holistic environmental education, ecosystems, environmental protection.

\section{Summary}

The article addresses a very important issue, being the lack of a specific environmental protection scientific discipline in Poland. The actual situation in this extent is analysed and compared to the solutions of the EU based on the systematic basis accepted by the OECD.

The author presents methodological solutions in his study, which may serve as the basis for the creation of a substantive framework for the designation of a separate environmental protection scientific discipline. These assumptions are supported by holistic elements, which are essential to environmental management with regard for the concept of sustainable development.

Few people in Poland give much consideration to the fact that the issue of Environmental Protection is managed entirely randomly. At 
first glance, everything appears to be perfectly ordered. We have the Ministry of the Environment; Environmental Protection is taught at virtually every university.

Where then is the real problem for Environmental Protection?

The problem lies in the fact that from the beginning of the transformation of the Polish state at the turn of the 1980s and 90s, no scientific discipline was introduced in the form of Environmental Protection. The consequences of this error are increasingly felt, including by among others the population increasingly aware of its basic rights.

Priortothepoliticaltransformation, thelackofaseparateEnvironmental Protection scientific discipline was entirely understandable. It was connected with the functioning of the entire political-commercial system concept, for which the natural environment was regarded solely as a still not exhausted reservoir of natural resources. With such an ideology, it was difficult to discuss any systematic approach to environmental protection. The issue was, to put it mildly, not a priority. During those times there was absolutely no question of giving Environmental Protection the status of a scientific discipline. There was great hope that the expected political transformation would also bring changes in this field. Unfortunately the greatest changes occurred primarily in the area of the universality of academic education, with no effect at all on its quality. Lack of quality in education, affected the entire national system of academic education, including among others that broadly understood as Environmental Protection. As a matter of fact quantity is not synonymous with quality in any area of life.

The greatest paradox of the current situation in Poland is the plurality of the various established scientific units teaching Environmental Protection, which in reality operate without a dedicated scientific discipline, which Environmental Protection should be. Thus in Poland, we have among others: environmental universities, environmental science departments, institutes, or different types of interdepartmental environmental protection academic education centres. All these 
scientific units conduct education and scientific research, predominantly according to the original programme adapted to their own cadre of employees. Unfortunately, most frequently the cadre is composed of employees representing very diverse scientific disciplines, often having no connection with Environmental Protection. This is caused by the lack in Poland of established academic domain and lack of the discipline of Environmental Protection. Therefore no one is ultimately responsible for the methodology of teaching Environmental Protection. Indeed the inter-disciplinary nature of Environmental Protection justifies a very broad substantive scientific approach, yet the far going freedom in the interpretation of this approach causes an ever more visible decline in confidence in institutions engaged in environmental protection education.

The establishment of the Environmental Protection branch of studies at all tertiary education establishments, until recently still guaranteed that virtually each university or other institution, obtained a full intake of candidates for this type of study. The greatest problem is however the acquisition of an appropriate scientific cadre. In this case the interdisciplinarity of environmental protection enables a virtually free choice of personnel components for these studies. Thus the process of education itself, with the frequently random specialisations of the employed cadre and the programme minimalism of the Ministry of Science and Higher Education, which is in any case established to a lesser or greater degree by civil servants.

In vain may one seek in the Statute of the 24th of October 2005 (A) for a discipline, which would correspond to one of the most popular study subjects, this is not solely applicable to Poland. The issues connected with environmental protection are virtually unseen in the list of arts and sciences and artistic and scientific disciplines. In practice the science of biology with the discipline represented by ecology and environmental formation, is found within the discipline of agricultural science, they are the only subjects involving the broadly understood 
issue of environmental protection. Equally one, as also the second discipline, concerned a specified issue.

Ecology is a science, the subject of interest of which are the interactions between animals and their environment, equally intensive or extensive (Haeckel 1869). The objects of research are three levels of biological organisation in the form of: populations, ecological complex and ecosystem. From this brief description, it is probably clearly evident that ecology may not be treated as a panacea for environmental protection and even more so it may not be treated as an equivalent of this concept. Nor does environmental protection replace the discipline of Environmental Management, which is placed within the subject of Agricultural Sciences and not in Earth Sciences, thus automatically significantly narrowing its area of interest. These disciplines should possibly constitute methodologically important separate units, which might be found in the new discipline of environmental protection, if such were established. Environmental engineering, because of its specific characteristics, should remain where it is now within the domain of technical sciences, and is accepted in the OECD division of scientific disciplines.

The division of scientific fields and disciplines, in force in Poland, is not even partially adapted to the real needs of the educational process or social expectations. Earth Sciences, which should lead with regard to methodology in environmental protection, have no disciplines associated with the environment, which constitutes a contradiction in the system of the OECD division of scientific disciplines. In the OECD, environment is to be found in Earth and Related EnvironmentalSciences, connected to one of six disciplines and namely Natural Sciences with the disconnection of social aspects, which are to be found within Social and Economic Geography in the discipline of Social Sciences. Ecology and Environmental Management are not distinguished as separate disciplines.

In connection with the discussion, which for many years has continued in Poland, on the subject of establishing the discipline of 
Environmental Protection, one should appreciate that further delay of this decision will cause irreversible damage in Polish education and science. It should finally be decided, whether to accept the system identified with OECD, or to create a specifically Polish system. For the time being there is no determination to act visible in the Central Commission for Academic Degrees and Titles. Maintaining the current state of affairs will cause degradation of the scientific and academic environment, which apparently not everyone wishes to concern himself with.

The lack of substantive bases for the establishment of the scientific discipline of environmental protection equally seems to be increasingly unjustified. This is required not only by the needs of managing the environment, but also by the requirement of introducing the idea of sustainable development.

The concept of sustainable development has already been very precisely described and defined. It is primarily due to philosophy that the concept of sustainable development is slowly acquiring a new dimension not only in the cognitive but also in the practical sense (applied philosophy of sustainable development).

For many the scientific planes are progressively treated with everincreasing understanding. Unfortunately, this understanding does not always relate in fact to actual intrinsic values. A cause of this is certainly the far-reaching interdisciplinary characteristic of this concept and the range of meaning. (Józef M.Dołęga 2001: 7-68). On the one hand this interdisciplinariness is the strength of the concept of "sustainable development" on the other hand it is its weakness. The weakness is visible primarily through the prism of natural sciences indicating the direction of development for the issues of environmental protection, simultaneously constituting a substantive basis for sustainable development itself.

In natural sciences one is faced with a very varied scientific methodology, or applied specialist terminology, which frequently causes far-reaching "incompatibility" of the obtained research results. This 
"incompatibility" is often the cause of an utterly different interpretation of the same natural phenomena.

The lack of a unified and simultaneously defined approach to the issues of environmental protection is already observed at the level of basic concepts. The most popular example, of such choice is the freely applied changeability of the application of such concepts, such as ecology and environmental protection.

Many concepts applied to the description of natural phenomena do not have their own proper methodological reinforcement. This applies to even such basic concepts as e.g. Biosphere. This concept is most frequently invoked when the issue arises of the description of "global" environmental processes, thus replacing the whole methodology connected with the role of the ecosystem in the natural environment.

Use of concept at the level of Biosphere, only from the meaning aspect, brings us to the stage of holistic comprehension of the natural environment (Sandner 2008: 69-80). Today we realise increasingly that a holistic comprehension of the natural environment should not be connected automatically with the concept of Biosphere.

Biosphere actually embraces all essential spheres for the existence of life, but differs if only in the level of self-sufficiency bearing in mind the factor of energy and material flow itself.

Therefore also the understanding of environmental processes including the role, which should be filled by sustainable development, should be examined significantly lower bearing it in mind, as a reference to the natural organic level (Weiner 2003: 253). In order to understand the consecutive truth of a higher order, it is necessary to gather the appropriate knowledge at the level of the lower order (Odum 1998: 19).

However, the problem is that, practically speaking, we are unable at the current level of science to reach beyond the sphere of ecosystem. Insofar as the level of biological organisation increases, there is a clear decrease in the level of scientific cognition. This co-dependence has a very significant influence upon the construction of principles for sustainable development. The drawing up of scientific principles 
for this idea should primarily use the scientific achievements on the highest levels of biological organisation, which however are the least known scientifically.

The next substantive problem in the philosophy of sustainable development is the necessity of the interdisciplinary approach in natural sciences, which only then will be able to create the conditions for the definition of universal laws, essential in the holistic understanding of the environment.

Here the principle of Ockham's Razor is worth noting, first formulated by the medieval English theologist William Ockham (Dzik 2003: 69).

This researcher noticed that for the clarification of reality, it is unnecessary to use a greater quantity of independent conditions; one need not use a greater quantity than necessary. This principle embodies, not only the defining requirement for a reduction of described conditions in the forms of the laws of nature, but equally suggested the possibility of connecting these laws, or combining them in the so-called universal laws. The creation of laws, arising as a result of such a process of combination, constitutes a significant moment of progress in the development of the given field of science. The development of natural sciences at the moment of the formation of the idea of sustainable development does not however have complete regard for Ockham's principle.

However in the longer term many scientists, investigating nature consciously chose a very much more complex route in the scientific investigation of nature. However the route is not always completely scientifically justified. For researchers who have examined physicalchemical processes or biological choices, this very complex scientific route was significantly easier. Insofar as scientists, examining the phenomenon with the inclusion of the factor of time and space such an explanation encountered significant substantive difficulties. Among this latter group, are included: ecologists, palaeontologists or sedimentologists. 
In their interpretation of the laws of nature, they need a new dimension in the form of time and space. Therefore the familiar theory of the "single dimensional" image of the World, which was sufficient for such groups of researchers as physico-chemists, became a significant limitation for the latter. For this group it proved to be that numerous laws of nature have a range of application that is limited also in time as well as in space. Beyond the given boundaries others are substituted, which again have their defined range in the specified time dimension.

Ockham's Principle should be applied also to those theories constructed on the basis of the dimensions of time and space. The problems in the application by scientists, among others: ecologists of Ockham's Principle in the period of formation (at the beginning of the $80 \mathrm{~s}$ ) of the idea of sustainable development, left its mark on the understanding of the natural environment.

All laws of nature, operating simultaneously also functioned equally in the past. This principle is most well known under the slogan of geological actualism, or uniformititarism that became temporarily one of the basic elements in the understanding of the natural environment surrounding us (Botkin, Keller 1995: 38); an understanding of the environment on the basis of cause and effect on successive processes, which may become the cause for the philosophy of sustainable development.

The creation of the scientific bases for the research methodology of sustainable development is based at the moment mainly on predication, or envisaging the future condition of the natural environment, drawing conclusions on the basis of familiarity with its current condition and envisaging its metamorphosis of laws.

The solution from a scientific point of view is however in a certain sense imperfect and in many cases it is simply not valid. The imperfection of this solution lies in the impossibility of always envisaging future changes in the natural environment. Such as from these same causes, today one equally may not envisage the course of evolution on Earth. 
The number of processes, systems and unforeseeable environmental interactions, actually provide an abundance of illusionary impressions in the extent of construction of scientific theories.

Another scientific barrier creating serious problems in natural investigation is the so- called theory of levels of integration. This theory proposes that one may not envisage the properties of a higher level, knowing only the properties of a lower level. One may not envisage the properties of water, knowing only the properties of hydrogen and oxygen; one may not foresee the characteristics of ecosystems on the basis of familiarity with the characteristics of isolated populations. This has far-reaching consequences in the development, primarily of scientific investigation of the natural environment (including the introduction of principles for sustainable development), which continuously concentrates on these lowest levels of integration.

Eco-philosophy examining the social, political, ideological and economic conditioning and consequences of interaction between man and the surrounding environment, must base itself on processes, the character of which is holistic. This requires a complex examination of the issues for which a part is empirically verifiable; another part however remains always in the sphere that is inaccessible to empirical verification.

The establishment of the environmental protection scientific discipline should be based on its own developed research methodology based on the principles of sustainable development. The drawing up of these principles should create a new quality in issues of environmental management issues.

The process of managing the economy of Poland with its resources, or also in an ordinary enterprise, ever more clearly demands a very wide specialist knowledge in the extent of familiarity with processes that operate in the natural environment. Knowledge of these processes is essential for the taking of appropriate commercial decisions on a national, regional or enterprise scale. It is particularly significant at the moment when, as never before the drastically developing deficit of 
natural resources is felt by the populations of all countries. This deficit encompasses not only energy raw materials, but also other resources beginning with available fresh water, through agricultural land and ending with contamination of the environment (e.g. through emission of warming gases etc.).

In the process of environmental management, knowledge of natural processes examined on a holistic scale is supremely significant. Only this approach may create real conditions for the preparation of new principles of environmental management within frameworks to find new systems in the light of the concept of sustainable development. The problems of environmental management are becoming the crucial issue the contemporary communities. Without a deeper knowledge of the processes of which environmental management is composed, it is difficult today not only to take decisions correctly on a national, regional scale but equally on the scale of an enterprise. An enterprise, which utilises many environmental resources, frequently as a result of lack of appropriate knowledge (lack of specialised cadre), brings about degradation in a manner of which the enterprise is either less or more unaware. Such activity leads to dangers with environmental and social consequences, which equally have economic as also ethical dimensions.

The establishment of a new specialisation at the Cardinal Stefan Wyszynski University named "Environmental Management in Sustainable Protection", may significantly bring about not only an increase of pro-ecological awareness in students (to the level of a source of knowledge essential to taking administrative-environmental decisions), but equally introduce new methodological solutions constituting a basis for arguing the necessity of establishing the scientific discipline of environmental protection. 


\section{Bibliography}

\section{Literature:}

Botkin D., Keller E., 1995, Environmental Science: Earth as a living planet, John Wiley \& Sons Inc., New York.

Dołęga Józef M., 2001, Koncepcja sozologii systemowej, Wydawnictwo UKSW, Warszawa.

Dzik J., 2003, Dzieje życia na Ziemi, PWN, Warszawa.

Krebs Ch.J., 1996, Ekologia, PWN, Warszawa.

Odum E.P., 1982, Podstawy ekologii, PWN, Warszawa.

Sandner J., 2008, Wybrane aspekty procesów środowiskowych holistycznej edukacji przyrodniczej $w$ świetle idei zrównoważonego rozwoju, Problemy Ekorozwoju, Vol. 3, No 2, 69-80.

Wejner J., 2003, Życie i ewolucja bosfery, Wydawnictwo PWN, Warszawa.

\section{Legislation:}

(A) Uchwała Centralnej Komisji Do Spraw Stopni i Tytułów z dnia 24 października 2005 r. w sprawie określenia dziedzin oraz dyscyplin naukowych i artystycznych (M.P. 2005 nr 79 poz. 1120 ze zmianą w M.P. 2008 nr 97 poz. 843).

(B) Ustawa z dnia 24 października 2005 roku MP nr 79, poz. 1120 ze zmianą w MP z 2008 r. nr 97, poz. 843). 